Ткаченко О.І., Ткаченко О.А., Ткаченко К.О.

\title{
КОНЦЕПТУАЛЬНІ АСПЕКТИ ПРИДБАННЯ, МОДЕЛЮВАННЯ ТА ЗАСТОСУВАННЯ ЗНАНЬ
}

У статті проведено аналіз кониептуальних підходів до процесів отримання, генераиії нових знань з наявних даних $i$ знань. Розглянуто та проведено дослідження шляхів когнітивних досліджень (наприклад, створення, набуття та отримання нових знань).

Проаналізовано застосування основних джерел знань (наприклад, інша система знань, інша фізична система для деякої системи знань, сама система знань), яка або має, або створює елементарні знання та інші структури знань.

Описана KDD (Knowledge Discovery in Databases) - cфера забезпечення автоматизованих рімень щзодо аналізу даних та процесів генеращії знань. Було визначено, щчо знання формуються лише всередині якоїсь системи знань (наприклад, інтелект користувача, інтелектуальна система знань).

Описано основні поняття систем знань та їх поєднання за допомогою відповідної комп 'ютерної моделі.

Ключові слова: знання, система знань, подання знань, моделювання систем знань, управління знаннями.

Постановка проблеми. Для знань і систем знань важливим є вирішення проблем аналізу і створення нових знань, вирішення когнітивних проблем та проблем застосування знань для розв'язання практичних задач. Тому дослідження концептуальних аспектів придбання, моделювання та застосування знань $є$ актуальною проблемою.

Анаіз останніх досліджень і публікацій. $Є$ багато процесів, в яких користувачі отримують знання. Серед цих процесів в інженерії знань важливими $є$ : пізнання, виробництво та створення знань, навчання, сприйняття, розпізнавання, розуміння (тлумачення), придбання та виявлення знань. Ці процеси досліджуються, зокрема в [1 - 7]. В [1 - 4] розглянуто, в основному, технологічні аспекти, а в [5 - 7] увага приділяється більше філософським чи теоретичним аспектам роботи зі знаннями. Підходам, що об'єднують технологічність та гносеологічність, і присвячена дана робота.

Формулювання цілей статті (постановка завдання). Метою роботи є дослідження процесів, що відбуваються у світі знань, який поєднує різні системи знань, їх представлень та носіїв. Цілями роботи $є$ розгляд таких процесів, як пізнання, виробництво, здобуття, виявлення та обробка знань, управління знаннями та їх застосування. Ці процеси використовують різні способи подання (представлення) знань.

Для ефективного виробництва знань слід розробити багаторівневу модель виявлення знань, рівнями якої є: видобуток даних, пошук інформації та формування знань. Кожен із цих рівнів має декілька підрівнів. Наприклад, видобуток даних виконується на рівні вихідних даних, рівні інтерпретованих даних та рівні атрибутивних даних. Поділ видобутку даних, пошуку інформації та формування знань, а також їх підрівнів базується на загальній теорії інформації та системній теорії знань, що використовують математичні методи теорії множин, теорії категорій та загальної теорії властивостей.

Виклад основного матеріалу дослідження. Виробництво знань, навчання та набуття будемо розглядати як основні когнітивні процеси. Когнітивність притаманна інтелектуальним системам. Шляхами когнітивних досліджень, зокрема є: створення / виробництво нових знань; набуття знань / активне навчання, коли особа, що навчається (студент, курсант, учень, 
курсант, пізнавач тощо), активно здійснює пошук наявних знань в якійсь предметній області; отримання знань або результатів навчання особами, що навчаються.

Створення/виробництво знань відбувається на таких рівнях: особистому, груповому та соціальному. Особистий, груповий та соціальний інтелект i творчі здібності, що застосовуються до особистих / групових / соціальних знань, породжують (створюють, виробляють) нові знання. Слід зауважити, створення знань - індивідуальна дія, а виробництво знань є процесом, який складається 3 окремих дій щодо утворення знань. Виробництво знань можна трактувати як різновид набуття (отримання, вилучення) знань із системи, яка виробляє ці знання. Створення/виробництво знань має такі форми:

- генерація нових знань;

- перетворення існуючих знань в нові відомості/знання;

- еволюція знань;

- реорганізація/реструктуризація існуючих знань з метою отримання нових знань.

Вказані форми залежать від правил, що використовуються при визначенні класу форми. Наприклад, якщо правила дедукції (такі як modus ponens) трактуються як інструкції щодо генерації, то дедукція - це генерація знань. А якщо правила дедукції трактуються як інструкції щодо трансформації, то дедукція - це трансформація знань.

Різниця між трансформацією знань та реструктуризацією знань є відносною. Якщо розглядати знання як єдине ціле, то реструктуризація знань є різновидом трансформації знань. Якщо вважати елементи знань окремими об'єктами, то трансформація знань змінює ці елементи, тоді як реструктуризація знань змінює лише відношення між цими елементами.

Можна виділити такі способи генерації знань [1]:

- передчуття, коли модель об'єкту (явища, процесу) змінюється, виробляючи нові знання з відношень між передбаченням і тим, що спостерігається;

- привласнення знань, існуючих в іншій системі;

- артикуляція (експлікація та реконструкція) відношень у системі знань. Основні способи пізнання відповідають наступним джерелам знань:

- Особистий i соціальний інтелект та креативність, що застосовуються до особистих/соціальних знань.

- Матеріальна діяльність (спостереження, експерименти, запити на інформацію, пошук у книгах, базах даних (БД), Інтернеті тощо) є джерелом знань та досвіду. У свою чергу, досвід може дати нові знання тим, хто може вчитися на досвіді (як своєму, так і чужому). Форми матеріальної діяльності є різні, зокрема: спостереження; експериментування; практична діяльність; взаємодія; пошук; ігри (в тому числі й комп'ютерні) тощо.

- Носії знань (інші люди, книги, бази знань, ПК, Інтернет та соціальні мережі) можуть надавати знання самостійно.

Основними етапами засвоєння знань когнітивною (інтелектуальною) системою, зокрема, $€$ :

- пошук та вибір інформації,

- вилучення, збір та накопичення інформації,

- перетворення інформації у знання.

Усі ці етапи базуються на знанні системи пізнання. Тому можна сказати, що знання породжують (збільшують) знання. У набутті знань основними джерелами $є: ~ 3$ практики/досвіду; з міркувань/мислення та з авторитету/думки. Маємо таку класифікацію набуття знань:

- на практиці/досвіді означає, що когнітивний агент отримує знання 3 практичної діяльності;

- шляхом розмірковування (думки) означає, що знання набуваються на основі думки, яка вважається авторитетною (це може бути думка окремої людини чи соціальної групи, взята 3 якогось джерела);

- шляхом міркувань/мислення здійснюється в сенсі когнітивного агенту.

Пошук знань може здійснюватися згідно з одним із таких типів: 
- внутрішній, коли система здійснює пошук у власних сховищах знань / інформації, таких як пам'ять, БД або база знань;

- зовнішній, коли система здійснює пошук у своєму середовищі;

- змішаний, коли система здійснює пошук скрізь.

Пошук та відбір відповідних знань - це когнітивні процеси, засновані на знаннях, які система вже має. Справді, необхідно знати, що шукати, де шукати та які інструменти підходять для пошуку. Наприклад, сприйняття, розпізнавання об'єктів залежить від використання знань, що зберігаються в системі, і потребує вибору відповідних правил виведення нових знань.

Існують такі основні типи знань при їх виробництві/створенні: виробництво знань шляхом логічного висновку, що включає дедукцію та індукцію; виробництво процедурних/навчальних знань, наприклад, шляхом експериментів або трансформації; інтуїтивне виробництво знань шляхом підсвідомого споглядання, вгадування тощо.

Основними типами отримання знань або активного навчання $\epsilon[5,6]$ :

- отримання знань за допомогою пошуку,

- збір знань шляхом відбору,

- збір знань шляхом експлікації чи вилучення.

Часто ці процеси йдуть один за одним, формуючи активний цикл навчання.

Основними компонентами когнітивної продуктивності $є$ інтелект, наполегливість і креативність. Існують такі види інтелектуальної діяльності:

- репродуктивна - відбір і відтворення даних знань;

- обмежена продуктивна - пошук необхідних знань;

- продуктивна - створення/виробництво нових знань.

В деяких випадках вибір та/або відтворення знань можуть бути більш складними діями, ніж пошук чи створення нових знань. Щодо засобів досягнення результату слід вказати такі види інтелектуальної діяльності: репродуктивна інструментальна інтелектуальна діяльність; розширена інструментальна інтелектуальна діяльність; творча інтелектуальна діяльність.

Прикладом розширеної інструментальної інтелектуальної діяльності є використання логіки для побудови мов програмування та написання програм.

Класифікація інтелектуальної діяльності корисна тому, що:

- допомагає при вивченні пізнання та творчості з різних точок зору;

- дозволяє розробляти орієнтовану на людину когнітивну методологію та технологію;

- забезпечує теоретичну базу для розвитку когнітивних та творчих навичок.

Метакомпоненти контролюють функціонування штучного інтелекту, повідомляючи, що він повинен робити. Ці компоненти важливі при вирішенні проблем та прийнятті рішень.

Компоненти продуктивності - це процеси, які фактично виконують дії, що диктують метакомпоненти, дозволяючи користувачам сприймати проблеми та відношення між об'єктами предметної області, перетворюючи зображення та застосовуючи відношення до іншого набору термінів. Компоненти набуття знань використовуються для отримання нової інформації, вибору корисної інформації з нерелевантної інформації та побудови нових знань, поєднуючи різні частини інформації.

Введемо наступні тлумачення понять. Адаптація - процес внесення змін в об'єкт предметної області для кращого пристосування до навколишнього середовища. Формування - процес внесення змін у навколишнє середовище, щоб краще відповідати потребам користувача (системи, замовника тощо). Розміщення включає переосмислення поточної ситуації, зміну когнітивної моделі та схем поведінки, що використовуються. Акомодація внутрішнє формування ситуації в інтелектуальній системі, в розумі людини тощо. Асиміляція - процес пристосування до поточної ситуації без зміни ії інтерпретації, наприклад, шляхом зміни схем поведінки. Відбір - процес зміни місця розташування об'єкту на те, яке краще відповідає цілям цього об'єкту предметної області.

Існують такі основні джерела знань для деякої системи знань Е, яка має/створює елементарні знання та інші структури знань: 
- інша система знань R (наприклад, книга, БД, експерт).

- інша фізична система R (наприклад, молекула, атом, зірка, пристрій).

- сама система знань Е (наприклад, коли Е витягує/згадує власні знання чи виробляє нові знання).

Джерела знань можна поділити на: активні (ці джерела самі надсилають інформацію, i користувач лише приймає/не приймає те, що надіслано); реактивні (ці джерела надсилають інформацію у відповідь на запит); пасивні (ці джерела не надсилають інформацію, і тому користувач повинен «витягувати» інформацію з пасивних джерел).

Вилучення знань із джерела можна робити шляхом: взаємодії, коли вплив на джерело знань враховується чи ні; запиту до джерела, яке відповідає наданням відповіді на цей запит.

Важливими процесами, що відбуваються в системах знань різних предметних областей, $\epsilon$ переклад знань та інтеграція перекладу знань $[1,2,7]$.

Переклад знань - це передача знань з однієї предметної області в іншу та їх адаптація до нової предметної області. Інтеграція знань з різних предметних областей - це їх передача у спільну область та взаємна адаптація.

Наукове пізнання при дослідженні проблеми і відповідного отримання знань до системи, що відповідає цій проблемі, використовує такі процеси, як: теоретичні міркування; с спостереження та експеримент; інтуїтивне розуміння. Як правило, ці процеси є окремими, але залежать і підтримують один одного, розширюючись у паралельному режимі з кількома циклами та ітераціями.

Логічний висновок як засіб отримання нових знань $є$ формалізованим способом відображення теоретичного міркування. Основні методи міркування застосовуються до декларативних знань і знань у формі виразів/формул із використовуванням наукової/логічної мови. Для отримання властивостей операційних та репрезентативних знань використовуються дедукція і індукція.

Дедукиія - це тип логічного висновку про знання, що здійснюється шляхом застосування конкретних правил дедукції: $A \rightarrow B$ або $A * B$, де $A$ називається припущенням правила, $B$ - висновком правила, і кожне з них $є$ кінцевою кількістю виразів або формул. Наприклад, взявши вираз «X в $Y »$, можна побудувати правило дедукції:

“ $U$ знаходиться в $V$ ", “V знаходиться в $W$ " * "U знаходиться в $W$ ".

Застосовуючи це правило до тверджень «Ми живемо в Україні» та «Україна розташована в Європі» як $A$, можна вивести твердження «Ми живемо в Європі» як $B$. Цей висновок гарантує істинність висновку з урахуванням істинності припущень. У загальному випадку для отримання необхідного висновку слід застосовувати правила дедукції кілька разів.

Найчастіше уживаним правилом дедукції є modus ponens, що має вигляд:

$\phi, \phi \rightarrow \psi * \psi$, де $\phi$ і $\psi$ - твердження чи пропозиції. Це правило має таке значення: Якщзо $\phi \epsilon$ істинним, а фозначає $\psi$, то $\psi$ є істинним.

Дедукція використовується не стільки для виробництва знань, скільки для їх обгрунтування. Дедукцію формалізують рекурсивні алгоритми та більшість логічних систем.

Індукиія є формою логічного висновку, що дозволяє зробити висновок із загального твердження $з$ окремих випадків, які забезпечують докази цього загального твердження (висновку). Якщо докази не є повними, висновок може бути неправильним.

Аналіз обчислювальних процесів дозволяе виявити окремий вид індукції конструктивну математичну індукцію, яка називається рекурсією. Неформальна рекурсія методика, що, враховуючи значення $f(n)$ деякої функції, визначеної для натуральних чисел, дозволяє обчислювати значення $f(n+1)$. Цей прийом дозволяє обчислити всі значення функції $f$. При конструктивній математичній індукції опис загального кроку обчислень передбачає можливість виконувати обчислення для безкінечної кількості входів. Індуктивне міркування - це обчислення функції істини.

Можна виділити такі типи індукції при виробництві знань: індукцію спостереження (емпіричну індукцію), абстрактну індукцію. Індукція спостереження - це висновок, зроблений 
для великої колекції об'єктів, наприклад, подій, систем, процесів, на основі спостереження (експериментів) з деякою невеликою частиною цієї колекції. Абстрактна індукиія - висновок, зроблений для великої (часто безкінечної) колекції об’єктів на основі міркувань про якусь кінцеву невелику частину цієї колекції.

Статистичний висновок (один 3 видів імперативної індукції) дозволяє отримати властивості великого набору об'єктів статистичної сукупності, використовуючи дані про ці властивості, отримані 3 деяких невеликих підмножин всієї сукупності. Ці підмножини називаються зразками i відбираються відповідно до визначених правил. Дійсність статистичного висновку залежить від відповідності статистичної моделі, що використовується до проблеми для отримання висновку. Статистична модель складається з [2]:

- набору припущень, що стосуються всієї сукупності;

- правила відбору зразків;

- правила оцінки властивостей обраних зразків та для висновку з отриманих даних.

Використовуються такі типи припущень щодо моделювання:

- повністю параметричні (розподіли ймовірностей, які описують сукупність та процес, повністю описуються множиною/сімейством розподілів ймовірностей, що включає лише невелику кількість невідомих параметрів.

- непараметричні (припущення щодо сукупності та процесу формування статистичних даних мінімальні);

- напівпараметричні (припущення не є повними, як у повністю параметричних, але й не такі малі, як у непараметричних).

Існують логічні системи, які формалізуючи індукцію та індуктивне міркування, розробляють логічні уявлення лише для якоїсь математичної індукції, що є процедурою переводу в логічне числення.

Емпірична індукція моделюється та досліджується в теорії абстрактних моделей (автоматів, графів, мереж, тощо), алгоритмів та обчислень. Математичне моделювання емпіричної індукції може здійснюватися в одному 3 напрямків: теорії Соломоно про універсальний індуктивний висновок; індуктивний висновок, заснований на вивченні в межі; індуктивний висновок, заснований на індуктивних машинах Тьюрінга. Підхід Соломоно трактує здобуття знань як здобуття здатності передбачати символ у послідовності на основі знання попередніх символів із цієї послідовності. Основне припущення в цій теорії полягає в тому, що символи в послідовності слідують деякому обчислюваному розподілу ймовірностей.

Мета індуктивного висновку - розпізнати функцію з урахуванням деяких ії значень. Процес індуктивного висновку виконується абстрактним автоматом - індуктивною машиною Тьюрінга, що стало кроком у розвитку інформатики, забезпечуючи більш адекватні та ефективні моделі для сучасних комп’ютерів (ПК) і комп’ютерних мереж та становлення класу суперрекурсивних алгоритмів.

Інтуїтивне знання - це сприйняття певної згоди/незгоди двох безпосередньо зіставлених ідей, тобто інтуїція обмежується знанням ідей. Інтуїиія - це пропозиційне ставлення, яке або здається істинним, або воно представляється суб'єкту як істинне, або спонукає суб'єкта повірити в те, що представлені в ньому пропозиції є істинними.

Поняття - це уявлення, які є загальними та опосередкованими, тоді як інтуїція $\epsilon$ окремими, безпосередніми уявленнями. Досвід - це поєднання інтуїції з поняттям у формі судження. Таким чином, для людини інтуїція відіграє принципово важливу роль у створенні знань. Інтуїція відображає аспекти реальності, а не лише враження від цих аспектів. Можна виділити, зокрема, такі типи інтуїтивного виробництва знань: аналогія; розширення або узагальнення. У цьому контексті розширення є формою логічного висновку від менш загального до більш загального. При виробництві знань використовується інформація, що належить до одного з таких типів:

- звичайна інформація, яка діє на центр міркувань (ця інформація дає знання, змінює переконання та генерує ідеї, таким чином, ії можна називати когнітивною інформацією);

- $\quad$ емоційна інформація (ії ще називають ефективною інформацією); 
- $\quad$ регулятивна (або пряма ефективна інформація).

Когнітивна інформація змінює вміст системи знань (тезаурус) та іiі носія. Пряма дієва інформація $\epsilon$ загальнішою, ніж пряма емоційна інформація. Існують різні підходи до формалізації інтуїтивного виробництва знань:

- $\quad$ Ймовірнісний пiдxiд, який поєднує класичну логіку та теорію ймовірностей (ймовірнісні логіки, логіки ймовірностей). В ймовірнісних логіках значення істини не обмежуються лише двома значеннями (істинне та хибне) як у традиційних логіках, а є ймовірністю бути справжнім виразом. У порівнянні зі звичайними логіками, ймовірнісні логіки забезпечують формалізми з широким спектром можливих сфер застосування. Однак ймовірнісні логіки мають й недоліки: висока обчислювальна складність обробки ймовірнісних та логічних компонентів; наявність можливості контр-інтуїтивних результатів.

- Підхід, щзо базується на нечітких логіках та лінгвістичних змінних.

Одним з напрямків застосування ПК для отримання знань $є$ їх виявлення у БД за допомогою KDD (Knowledge Discovery in Databases) [8]. KDD - це процес пошуку корисних знань в так званих "сирих" даних. Знання отримуються шляхом пошуку інформації, який базується на зборі даних, видобутку та аналізі. Обсяг даних, що є в БД, сьогодні значно перевищує нашу здатність аналізувати дані без використання методів автоматизованого аналізу. KDD спрямований на підвищення ефективності обробки інформації.

KDD - це сфера, яка забезпечує автоматизовані рішення з аналізу даних та визначення процесів, в яких знання $\epsilon$ кінцевим продуктом, а дані $\epsilon$ вихідним джерелом. Етапом у цьому процесі $\epsilon$ видобуток даних, який полягає у застосуванні конкретних алгоритмів для вилучення даних. Для роботи з БД були розроблені різні методи видобутку даних. Однак аналіз даних, хоча і дає більш узагальнені та/або адекватні дані, але не дає знань як таких. Наприклад, пошук даних в Інтернеті надає користувачеві великі обсяги даних, але користувач має сам перетворити ці дані у знання. Знання формуються лише всередині якоїсь системи знань. Це може бути розум користувача або автоматизована система знань на ПК.

KDD надає можливість виявляти нову та значущу інформацію за допомогою наявних даних. Обсяг даних, що потребує обробки у великій БД, перевищує можливості людини, а труднощі перетворення вихідних даних у знання перевищують межі традиційних БД. Повне використання збережених даних залежить від методів виявлення знань. KDD $\epsilon$ інтерактивним та ітеративним, включаючи ітерації та цикли, що вимагають від користувача багатьох рішень. Основними етапами процесу KDD є:

- розуміння області застосування, пошук відповідних попередніх знань та визначення цілей процесу KDD з точки зору замовника;

- формування цільової сутності в БД вибір набору даних чи зосередження уваги на підмножині змінних/зразках даних, на яких необхідно виконати виявлення знань);

- очищення та попередня обробка даних, включаючи видалення шуму, збір необхідної інформації для моделювання чи обліку шуму, прийняття рішення щодо стратегій обробки відсутніх даних та/або полів даних;

- скорочення даних $i$ змінних для пошуку функцій та інваріантних подань обраних даних залежно від мети/завдання;

- узгодження иілей KDD з методом видобутку даних (узагальнення, класифікація, регресія, кластеризація тощо);

- аналіз з вибором моделі, вибором алгоритмів отримання даних і методів пошуку шаблону даних;

- отримання (видобуток) даних, який здійснює пошук моделей, що цікавлять у певній формі репрезентації або наборі таких подань, включаючи правила класифікації, дерева, регресію, кластеризацію тощо;

- інтерпретація видобутих шаблонів, візуалізація шаблонів, моделей та/або даних, отримання знань і повернення до будь-якого з попередніх етапів для подальшої ітерації;

- дія на виявлені знання шляхом використання знань, включення знань в іншу систему для подальших дій або відповідного документування. Цей процес включає перевірку та 
вирішення конфліктів з наявними або витягнутими (отриманими) знаннями.

Існує багато методів, класифікованих як методи KDD і використовуваних для пошуку інформації та виявлення знань, зокрема, це кількісні методи (ймовірнісний та статистичний) та схеми KDD, які використовують методи візуалізації, класифікаційні підходи до KDD (такі як байєсівська класифікація, індуктивна логіка, очищення даних / виявлення закономірностей та аналіз дерева рішень), інші підходи, що включають відхилення та аналіз тенденцій, генетичні алгоритми, нейронні мережі та гібридні методології.

Іншими популярними методами виявлення та набуття знань на основі ПК $\epsilon$ розпізнавання образів (зразків), комп'ютерне моделювання (КМ), алгоритми навчання та технологія експертних систем. КМ є важливою частиною експериментів у багатьох сферах, наприклад, фізика високих енергій, в якій КМ знижує вартість експериментів та зберігає середовище від негативного впливу деяких фізичних експериментів. Дослідження основ когнітивних процесів використовують математичне моделювання, КМ та поведінкові експерименти.

Сучасна інженерія знань приділяє велику увагу розробці, наприклад, інтелектуальних систем доведення теорем, дедукції та загальних міркувань. Автоматизоване доведення теорем використовується, наприклад, для перевірки правильності програмного забезпечення (ПЗ) та відповідного апаратного забезпечення.

Планування процесів знань та оцінка результатів включає побудову та вдосконалення систем знань, ефективне вбудовування систем знань у робочі системи. Управління знаннями висуває вимоги до стратегічного розуміння, здатності вирішувати проблеми людини, яка бере участь у цій діяльності [9].

Щоб бути ефективним, КМ процесів отримання нових знань повинно грунтуватися на: визначенні та ідентифікачї̈ потреб у тих чи інших знаннях; виявленні та пошуку початкових (вихідних) знань/інформації; перетворенні даних у знання; створенні/виробництві знань (генерації/конструюванні загальних нових знань або реконструкції локально нових знань); отриманні знань (отриманні інформації, надісланої іншою системою, та перетворенні ії у знання); набутmі знань, яке має різні форми (прийняття створених, отриманих або знайдених знань в систему); фіксаиї наявних неявних знань і перетворення їх у явні знання за допомогою спідкування інженерів знань 3 експертами, які мають ці неявні знання; привласненні та представленні знань (отриманні знань, придатних для визначених людей, завдань, організацій, шляхом трансформації знань, подання знань і носіїв знань); кодифікації знань (зміні представлення знань, спрямованій на розміщення знань у структурованому сховищі за допомогою моделей знань); зберіганні знань (накопиченні знань у фізичному сховищі (БД, базі знань, бібліотеці чи архівах)); інтеграції знань, яка має декілька форм (інтеграція однієї системи знань в іншу, перетворення декількох систем знань в одну, інтеграція системи знань у деяку сферу діяльності тощо); оиінці знань активів (пошуку важливих властивостей, параметрів, характеристик та атрибутів знань в тій чи іншій предметній області); обміні та розповсюдженні знань; приховуванні знань (захисті знань від несанкціонованого доступу); перекладi знань (передачі знань від одного до іншого); niдтримщі знань, що складається 3 дій, спрямованих на модифікацію, оновлення та корекцію знань таким чином, щоб підтримувати їх в експлуатації та прийнятними для своїх користувачів, збільшуючи їх корисність); застосуванні, впровадженні та використанні знань; моніторингу знань (в тому чисі контролю та оцінки використання знань); обміні знаннями 3 іншими користувачами; перегляд $i$ знань (оцінці ситуації та зміні знань, коли це обгрунтовано чи необхідно); вилученні знань.

Кожен із видів діяльності в процесі управління знаннями передбачає: визначення цілей; визначення рішень; організацію та реалізацію діяльності; оцінку результату. Всі ці заходи тривають одночасно, формуючи різні цикли. Наприклад, пошук знань може бути повторений кілька разів, перш ніж буде отриманий результат, або цикл створення знань - привласнення знань - зберігання знань проводиться багато разів протягом усього КМ. Важливою складовою 
управління знаннями $є$ організаційний цикл знань, який передбачає: набуття знань; поширення знань; використання знань.

Деякі з цих видів діяльності, наприклад, кодифікація знань або зберігання знань, включають лише явні знання, тоді як інші, наприклад, створення знань або привласнення знань, включають як явні, так і неявні знання. Набуття знань включає вилучення, збір, аналіз, моделювання та перевірку знань.

Всі дослідження та застосування системи управління знаннями концентрують свою увагу на знаходженні, створенні, придбанні та зберіганні знань [9]. Але захист знань за допомогою приховування знань ще й досі використовується не в повній мірі. На відміну від обміну знаннями, приховування - це навмисне приховування запитаних шуканих іншим користувачем знань. Існують такі способи приховування знань: ухильне приховування, раціоналізоване приховування та «гра в німого» $[10,11]$.

Ще однім процесом який досліджується недостатньо, є вивільнення знань. Забувати це важливий принцип ефективного управління знаннями. Забуття, тобто усунення або видалення знань, важливе коли:

- в базі знань необхідно звільнити місце для нових знань (тут необхідно правильно вибрати те, що можна видалити);

- нові знання суперечать збереженим знанням;

- збереження старих знань може знизити ефективність системи;

- деякі знання можуть зашкодити системі, їх усунення є життєво важливим.

Підтримка знань в основному розробляється для оперативних знань у вигляді комп'ютерного та мережевого ПЗ. Багато компаній IT-сфери пропонують оновлення для вирішення різних проблем зі своїм ПЗ [11]. У той же час слід підтримувати описові та репрезентативні знання. Наприклад, важливо постійно оновлювати інформацію в БД та базах знань, бо застаріла інформація може бути дуже шкідливою. Такі процеси постійно відбуваються в системах веб-пошуку, що постійно оновлюють збережені дані пошуку.

Висновки. У статті було визначено, що управління знаннями відбувається в системі, яка має такі основні компоненти: користувачі, технології та процеси. Процеси визначають ролі та знання, необхідні користувачам/системам, тоді як технології забезпечують підтримку людей. Процеси визначають потреби в технології, а технологія робить можливими нові види процесів.

Слід зауважити, що управління знаннями є дуже популярною сферою досліджень. Крім того, важливо розуміти, що знання самі по собі не вирішують проблем користувачів. Навіть маючи найкращі знання, користувачі/системи часто не роблять або не можуть робити те, що необхідно для досягнення поставлених цілей.

Таким чином, надзвичайно важливо не тільки, як організовані процеси придбання нових знань, моделювання знань у відповідних системах знань, але дуже важлими є процеси застосування/використання знань.

Проведений аналіз концептуальних аспектів отримання, моделювання та використання знань сприятиме формуванню цілісного підходу до процесів інженерії знань.

\section{ЛІТЕРАТУРА}

1. Valiant J. Strategic knowledge engineering. [Electronic resourse]. - URL: http://cranedge.wordpress.com/2010/11/15/strategic-knowledge-engineering/

2. Гаврилова Т.А., Кудрявцев Д.В., Муромцев Д.И. Инженерия знаний. Модели и методы. М.: Изд-во Лань, 2016. 324 с.

3. Головко В.А., Краснопрошин В.В. Нейросетевые технологии обработки данных. Мінськ: БГУ, 2017. 263 с.

4. Рассел С., Норвиг П. Искусственный интеллект: современный поход. М.: Изд. дом «Вильямс», 2006. 1408 с.

5. Bellinger G., Castro D., Mills A. Data, Information, Knowledge, and Wisdom. [Electronic resourse]. - URL: http://www.outsights.com/systems/dikw/dikw.htm. 
6. Bengson J. Moett M.A. Two conceptions of mind and action: Knowing how and the philosophical theory of intelligence. Knowing How: Essays on Knowledge, Mind and Action. Oxford: Oxford University Press, 2012. pp. 3-58.

7. Душкин Р.В. Методы получения, представления и обработки знаний с НЕ-факторами. [Електронний ресурс]. - Режим доступу: file://C:/Users/Olga/Downloads/Mетоды\%20

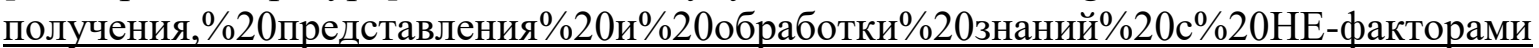

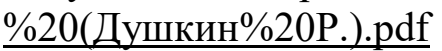

8. Knowledge Discovery in Databases - обнаружение знаний в базах данных. [Електронний ресурс]. - Режим доступу: https://basegroup.ru/community/articles/kdd

9. Управление знаниями. [Електронний ресурс]. - Режим доступу: https://sites.google.com/site/upravlenieznaniami/inzeneria-znanij

10. Модели и методы представления и организации знаний. [Електронний ресурс]. Режим доступу: http://it-claim.ru/Library/Books/Semantics_IT/gl1_1/glava1_1.htm

11. Edwards, J. S.) A process view of knowledge management: It ain't what you do, it's the way you it //Electronic Journal of Knowledge Management. 2011. V. 9. No. 4. pp. 297-306.

\section{Tkachenko O.I, Tkachenko O.A, Tkachenko K.O.}

\section{CONCEPTUAL ASPECTS OF ACQUISITION, MODELING AND APPLICATION OF} KNOWLEDGE

The article analyzes the conceptual approaches to the processes of obtaining, generating new knowledge from existing data and knowledge. The researches of ways of cognitive researches (for example, creation, acquisition and acquisition of new knowledge) are considered and carried out.

The application of the main sources of knowledge (for example, another system of knowledge, another physical system for some system of knowledge, the system of knowledge itself), which either has or creates elementary knowledge and other knowledge structures, is analyzed.

KDD (Knowledge Discovery in Databases) is described - the field of providing automated solutions for data analysis and knowledge generation processes. It was determined that knowledge is formed only within a system of knowledge (eg, user intelligence, intelligent knowledge system).

The basic concepts of knowledge systems and their combination using the appropriate computer model are described.

Keywords: knowledge, knowledge system, knowledge representation, modeling of knowledge systems, knowledge management.

\section{Ткаченко О.И., Ткаченко А.А., Ткаченко К.А.}

\section{КОНЦЕПТУАЛЬНЫЕ АСПЕКТЫ ПРИОБРЕТЕНИЯ, МОДЕЛИРОВАНИЯ И ПРИМЕНЕНИЯ ЗНАНИЙ}

В статье проведен анализ концептуальных подходов к прочессам получения, генерации новых знаний из имеюшихся данных и знаний. Рассмотрено и проведено исследование путей когнитивных исследований (например, создания, приобретения и получения новых знаний).

Проанализировано применение основных источников знаний (например, другая система знаний, другая физическая система для некоторой системы знаний, сама система знаний), которая либо имеет, либо создает элементарные знания и другие структуры знаний.

Описана KDD (Knowledge Discovery in Databases) - cфера обеспечения автоматизированных решений по анализу данных и процессам генерации знаний. Было определено, что знания формируются только внутри какой-то системы знаний (например, интеллект пользователя, интеллектуальная система знаний).

Описаны основные понятия систем знаний и их сочетания с помощью соответствующей компьютерной модели.

Ключевые слова: знания, система знаний, представление знаний, моделирование систем знаний, управления знаниями. 